\title{
Efficient Production of Acetic Acid from Nipa (Nypa fruticans) Sap by Moorella thermoacetica (f. Clostridium thermoaceticum)
}

\author{
Dung Van Nguyen, Pinthep Sethapokin ${ }^{\S}$, Harifara Rabemanolontsoa, Eiji Minami, \\ Haruo Kawamoto and Shiro Saka
}

\author{
Department of Socio-Environmental Energy Science, Graduate School of Energy Science, Kyoto University, \\ Yoshida-honmachi, Sakyo-ku, Kyoto 606-8501, Japan
}

\begin{abstract}
To valorize the underutilized nipa sap composed mainly of sucrose, glucose and fructose, acetic acid fermentation by Moorella thermoacetica was explored. Given that $M$. thermoacetica cannot directly metabolize sucrose, we evaluated various catalysts for the hydrolysis of this material. Oxalic acid and invertase exhibited high levels of activity towards the hydrolysis of the sucrose in nipa sap to glucose and fructose. Although these two methods consumed similar levels of energy for the hydrolysis of sucrose, oxalic acid was found to be more cost-effective. Nipa saps hydrolyzed by these two catalysts were also fermented by $M$. thermoacetica. The results revealed that the two hydrolyzed sap mixtures gave $10.0 \mathrm{~g} / \mathrm{L}$ of acetic acid from the $10.2 \mathrm{~g} / \mathrm{L}$ of substrate sugars in nipa sap. Notably, the results showed that the oxalic acid catalyst was also fermented to acetic acid, which avoided the need to remove the catalyst from the product stream. Taken together, these results show that oxalic acid hydrolysis is superior to enzymatic hydrolysis for the pretreatment of nipa sap. The acetic acid yield achieved in this study corresponds to a conversion efficiency of $98 \%$, which is about 3.6 times higher than that achieved using the traditional methods. The process developed in this study therefore has high potential as a green biorefinery process for the efficient conversion of sucrose-containing nipa sap to bio-derived acetic acid.
\end{abstract}

Keywords: Sucrose hydrolysis, Oxalic acid, Invertase, Acetic acid fermentation, Process simulation, Biorefinery.

\section{INTRODUCTION}

Nipa (Nypa fruticans) is a high sugar-yielding palm that can be found along coastal areas, river estuaries and mangrove forests with brackish water environments [1]. By removing the infructescence of this plant, it is possible to collect a sugar-rich sap from its stalk on a daily basis for a minimum of 60 days in the Philippines and up to 340 days in Malaysia [2]. Furthermore, nipa sap production ranges from 0.5 to $2.5 \mathrm{~L} /$ palm/day with an average sugar content of $16.4 \mathrm{w} / \mathrm{v} \%[3,4]$.

According to Tamunaidu et al. [5], the major components of nipa sap are sucrose, glucose and fructose [6], which can be used for different purposes. For instance, fresh tapped nipa sap is consumed as a popular sweet drink in the coastal areas of Southeast Asia [7]. Additionally, some villages in Thailand earn a living from tapping and selling nipa sap for wine and sugar production [7]. In the Philippines, nipa sap is poured into huge earthen jars, where it is kept for up to a month for acetous fermentation to produce vinegar [8]. Despite its high potential as a source of raw materials, nipa palm is tapped limitedly by local communities for domestic use with no reported international trade [9].

\footnotetext{
*Address correspondence to this author at Department of SocioEnvironmental Energy Science, Graduate School of Energy Science, Kyoto University, Yoshida-honmachi, Sakyo-ku, Kyoto 606-8501, Japan; Tel: +81 75753 4738; Fax: +81 75753 4736;

E-mail: saka@energy.kyoto-u.ac.jp

§On leave from King Mongkut's Institute of Technology Ladkrabang to Kyoto University.
}

Nipa is an abundant plant material in Asia, where it is regarded as a non-threatened and underutilized sugar-yielding palm [10]. It is noteworthy that nipa sap was recently assessed as a high potential feedstock for bioethanol production [11]. In fact, estimated annual ethanol yield of 3,600-22,400 L/ha/year from nipa sap [12] makes it an attractive raw material for ethanol production compared to sugarcane and corn, which afford yields of 5,300-6,500 and 3,100-3,900 L/ha/year, respectively [13]. Nipa sap could therefore become a promising source of sugars for manufacturing bioproducts.

Acetic acid is one of the most important industrial reagents in the world. Acetic acid has a broad range of applications, including its use as building block for the synthesis of monomeric vinyl acetate, ethyl acetate, butyl acetate and acetic anhydride, as well as its use as a solvent for the production of purified terephthalic acid $[14,15]$. However, acetic acid is mainly produced from petrochemical resources via methanol carbonylation and the liquid-phase oxidation of butane, naphtha and acetaldehyde [16]. In light of dwindling fossil fuel supplies and the push for new environmentally manufacturing processes based on renewable resources, there has been considerable interest in the production of acetic acid via bio-based routes [15].

Traditional processes for the production of vinegar from nipa sap involve a two-stage fermentation process in which alcohol is initially formed by yeast and subsequently converted to acetic acid by aerobic bacteria 
$[17,18]$. As shown in equation (1), two moles of carbon are lost during this process in the form of $\mathrm{CO}_{2}$, leading to low carbon conversion efficiency.

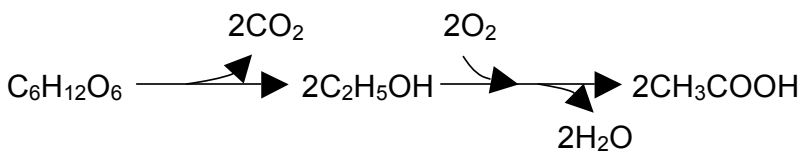

In contrast, among the acetogenic bacteria, Moorella thermoacetica can directly convert glucose and fructose to acetic acid as a single product in a stoichiometric manner $[19,20]$, according to the equation provided below.

$$
\mathrm{C}_{6} \mathrm{H}_{12} \mathrm{O}_{6} \rightarrow 3 \mathrm{CH}_{3} \mathrm{COOH}
$$

Notably, this fermentation process does not emit any $\mathrm{CO}_{2}$, and can therefore achieve a higher conversion efficiency than the traditional process described above.

Although $M$. thermoacetica has been investigated extensively for the conversion of model compounds [21-24], it has not been investigated for its conversion of natural sugar sources such as nipa sap because it contains non-fermentable sucrose $[19,21]$. With this in mind, the aim of the current study was to evaluate the potential use of nipa sap for the efficient bio-derived production of acetic acid.

\section{MATERIALS AND METHODS}

\subsection{Materials}

The nipa sap used in this study was collected from Sarawak in Malaysia. For conservation and transportation purposes, the sap was concentrated by heating to give a viscous liquid. Prior to the experiments described in this study, $200 \mathrm{~g}$ of concentrated nipa sap was diluted with deionized water to a total volume of 1 $\mathrm{L}$, which gave a sugar concentration similar to that of the original sap. Invertase solution (EC No.3.2.1.26) with a minimal activity of 4 units $/ \mathrm{mL}$ was purchased from Wako Pure Chemical Industries Ltd. (Osaka, Japan). Freeze-dried cultures of $M$. thermoacetica, which is also known as Clostridium thermoaceticum (ATCC 39073), were obtained from the American Type Culture Collection (Manassas, VA, USA).

\subsection{Acid Hydrolysis}

Three different acids, including acetic acid, oxalic acid and hydrochloric acid were evaluated as catalysts for the hydrolysis of sucrose in the pretreatment step.
For the hydrolysis reactions conducted with acetic acid, 0-20 g/L of the acid catalyst was added to the nipa sap in a $20 \mathrm{~mL}$ vial, and the resulting mixture was heated in an autoclave at $121{ }^{\circ} \mathrm{C}$ for various reaction times. The reaction mixtures were then removed from the autoclave and rapidly chilled in a refrigerator to room temperature before being neutralized $(\mathrm{pH} 7.0 \pm 0.1)$ by the addition of an appropriate buffer solution. The hydrolysis of sucrose in nipa sap was conducted in a similar manner with $1.5-4.5 \mathrm{~g} / \mathrm{L}$ oxalic acid and $3.0 \mathrm{~g} / \mathrm{L}$ hydrochloric acid.

\subsection{Enzymatic Hydrolysis}

The enzymatic hydrolyses were performed in a metal bath at 25 and $60{ }^{\circ} \mathrm{C}$ with a $3.92 \mathrm{v} / \mathrm{v} \%$ invertase solution. The reactions were subsequently treated with boiling water for $5 \mathrm{~min}$ to destroy the invertase activity.

\subsection{Acetic Acid Fermentation}

The revival of $M$. thermoacetica from a freeze-dried state and the subsequent preparation of the corresponding inoculum were conducted according to the procedures reported by Nakamura et al. [22].

M. thermoacetica was used to produce acetic acid in a $\mathrm{pH}$-controlled batch fermentation process, which was conducted in a $500 \mathrm{~mL}$ DPC-2A fermentation system (Able Corporation, Tokyo, Japan) at $60^{\circ} \mathrm{C}$ with a stirring rate of $300 \mathrm{rpm}$. The nutrients in the broth were similar to those used by Rabemanolontsoa et al. [25], and consisted of the following chemicals: $5 \mathrm{~g} / \mathrm{L}$ yeast extract, $0.1 \mathrm{~g} / \mathrm{L}$ cysteine $\cdot \mathrm{HCl} \cdot \mathrm{H}_{2} \mathrm{O}, 1 \mathrm{~g} / \mathrm{L}\left(\mathrm{NH}_{4}\right)_{2}$ $\mathrm{SO}_{4}, 0.25 \mathrm{~g} / \mathrm{L} \mathrm{MgSO}{ }_{4} \cdot 7 \mathrm{H}_{2} \mathrm{O}, 0.04 \mathrm{~g} / \mathrm{L} \mathrm{Fe}\left(\mathrm{NH}_{4}\right)_{2}\left(\mathrm{SO}_{4}\right)_{2}$. $6 \mathrm{H}_{2} \mathrm{O}, 0.24 \mathrm{mg} / \mathrm{L} \mathrm{NiCl} \cdot 6 \mathrm{H}_{2} \mathrm{O}, 0.29 \mathrm{mg} / \mathrm{L} \mathrm{ZnSO} \cdot 7 \mathrm{H}_{2} \mathrm{O}$, $0.017 \mathrm{mg} / \mathrm{L} \mathrm{Na}_{2} \mathrm{SeO}_{3}$ and $1 \mathrm{mg} / \mathrm{L}$ resazurin. The nutrients were weighed and dissolved in $166 \mathrm{~mL}$ of Milli-Q water. The fermentation systems and nutrient solutions were autoclaved at $121{ }^{\circ} \mathrm{C}$ for $20 \mathrm{~min}$ to allow for their sterilization. An anaerobic environment was then prepared by filling a glove box with $\mathrm{N}_{2}$ gas and a working volume of $200 \mathrm{~mL}$ was created in each of the fermentation systems by pouring $14 \mathrm{~mL}$ of hydrolyzed nipa sap, $20 \mathrm{~mL}$ of $M$. thermoacetica inoculum and $166 \mathrm{~mL}$ of nutrient solution into each fermentation system. The fermentation process conducted under an atmosphere of $\mathrm{N}_{2}$ was maintained at $\mathrm{pH} 6.5 \pm 0.1$ by automatic titration with $2 \mathrm{~N} \mathrm{NaOH}$. Samples were collected from the fermentation broth at specific time points through a sampling port with a sterile syringe, and then stored at $-31{ }^{\circ} \mathrm{C}$ prior to being analyzed by high-performance liquid chromatography (HPLC) on an LC-10A HPLC 
system (Shimadzu, Kyoto, Japan). Blank samples consisting of Milli-Q water and the catalysts instead of the hydrolyzed nipa sap were also run under the same conditions to correct for the acetic acid produced by the nutrients, inocula and catalysts.

\subsection{Analyses}

The concentrations of the individual sugars and ethanol in the samples were analyzed by HPLC using a Shodex sugar KS-801 column (Showa Denko, Kanagawa, Japan). The column was eluted with water at a flow rate of $1.0 \mathrm{~mL} / \mathrm{min}$ with a column temperature of $80{ }^{\circ} \mathrm{C}$. The concentrations of the organic acids present in the samples were determined by HPLC analysis over an Aminex HPX-87H column (Bio-rad, Hercules, CA, USA), which was eluted with a $5 \mathrm{mM}$ aqueous $\mathrm{H}_{2} \mathrm{SO}_{4}$ solution with a flow rate of $0.6 \mathrm{~mL} / \mathrm{min}$ at a column temperature of $45{ }^{\circ} \mathrm{C}$. The inorganic elements in the nipa sap were analyzed by ion chromatography (IC) and inductively coupled plasma mass spectrometry (ICP-MS) at AU Techno Services Co., Ltd. (Osaka, Japan).

To evaluate hydrolysis efficiency, sucrose conversion to glucose and fructose and the glucose and fructose yield were estimated using the following equations:

$$
\text { Sucrose conversion }(\%)=\frac{\text { Hydrolyzed sucrose }(\mathrm{g} / \mathrm{L})}{\text { Initial sucrose }(\mathrm{g} / \mathrm{L})} \times 100
$$

$\begin{gathered}\text { Glucose and } \\ \text { fructose yield }\end{gathered}(\%)=\frac{\text { Total glucose and fructose produced }(\mathrm{g} / \mathrm{L})}{\text { Total theoretical max. glucose and fructose produced }(\mathrm{g} / \mathrm{L})} \times 100$

\subsection{Process Simulation}

The process responsible for the production of acetic acid from nipa sap was simulated using version 9.3 of the Pro/II ${ }^{\mathrm{TM}}$ software with a nipa sap fed rate of 750 $\mathrm{kg} / \mathrm{h}$, as shown in Figure 1. This simulation was designed as a two-stage process, including (i) the acid or enzymatic hydrolysis of sucrose; and (ii) the fermentation of acetic acid.

For the acid hydrolysis reactions, nipa sap was mixed with one of three acids, and the resulting mixture was fed into an autoclave operating at $121{ }^{\circ} \mathrm{C}$ for simultaneous hydrolysis and sterilization processes. For the enzymatic treatment process, the hydrolysis and sterilization treatments were conducted separately because they required different operating temperatures. To save energy, the stream derived from the hydrolyzed nipa sap was used to heat the untreated nipa sap prior to it being sent to the autoclave. After the hydrolysis reaction, the hydrolyzed nipa sap was depressurized to atmospheric pressure and fed together with nutrients and an aqueous $\mathrm{NaOH}$ solution into a fermentation system at $60{ }^{\circ} \mathrm{C}$ and $101 \mathrm{kPa}$. The aqueous nutrient and $\mathrm{NaOH}$ solutions were preheated by the product from the fermentation system to save energy.

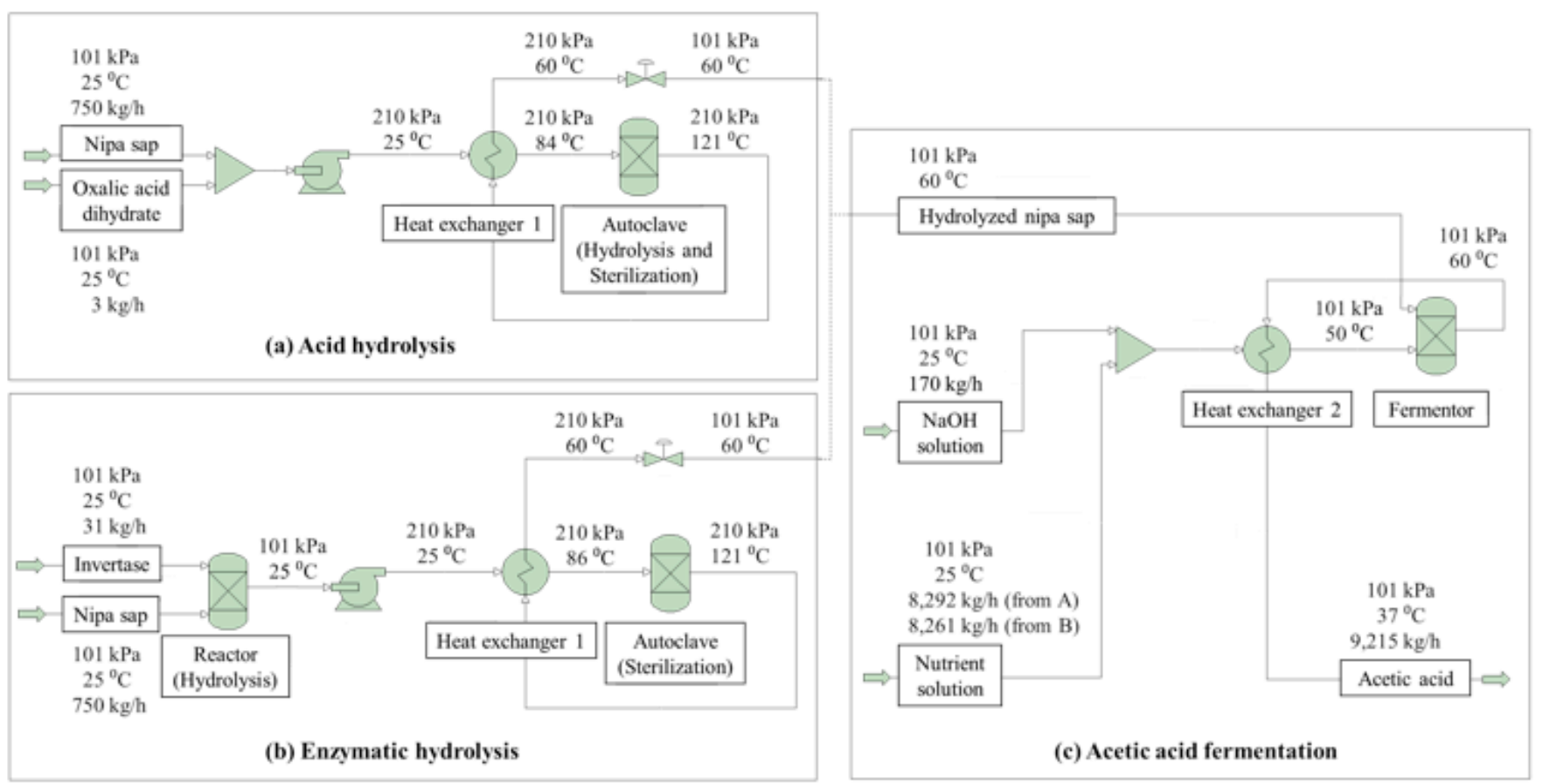

Figure 1: Schematic diagrams of (a) acid hydrolysis, (b) enzymatic hydrolysis, and the subsequent (c) acetic acid fermentation processes. 
The non-random two-liquid (NRTL) model was selected as the best model for the thermodynamic calculations conducted in the current study. Energy losses from the pipes and the individual units were neglected and the pump efficiency was set at $80 \%$. Furthermore, the counter-flow heat exchangers were configured to operate with a minimum internal temperature approach $\left(\Delta \mathrm{T}_{\min }\right)$ of $10^{\circ} \mathrm{C}$.

\section{RESULTS AND DISCUSSION}

\subsection{Chemical Composition of Nipa Sap}

The chemical composition of nipa sap from Malaysia is shown in Table 1. The results in the table show that Malaysian nipa sap is predominantly composed of sucrose $(78.4 \mathrm{~g} / \mathrm{L})$, glucose $(32.3 \mathrm{~g} / \mathrm{L})$ and fructose (31.4 g/L). Malaysian nipa sap also contains $1.7 \mathrm{~g} / \mathrm{L}$ of ethanol. The lactic acid found in this nipa sap accounts for $2.1 \mathrm{~g} / \mathrm{L}$ of its composition and undoubtedly makes a significant contribution to its acidic $\mathrm{pH}$ (4.37). According to Nur Aimi et al. [26], the sugars found in nipa sap can be gradually fermented to various products, such as ethanol, lactic acid and/or acetic acid, by several naturally occurring yeasts and bacteria [11]. However, acetic acid was not detected in this case.

Table 1: Chemical Composition of Malaysian Nipa Sap

\begin{tabular}{|c|c|c|}
\hline Chemical Composition & Concentration (g/L) & Content (wt\%) \\
\hline \multicolumn{3}{|l|}{ Organic Compounds } \\
\hline Sucrose & 78.4 & 7.31 \\
\hline Glucose & 32.3 & 3.01 \\
\hline Fructose & 31.4 & 2.93 \\
\hline Ethanol & 1.7 & 0.16 \\
\hline Lactic acid & 2.1 & 0.20 \\
\hline Total organics & 145.9 & 13.61 \\
\hline \multicolumn{3}{|l|}{ Inorganic Elements } \\
\hline $\mathrm{K}$ & 2.6 & 0.24 \\
\hline $\mathrm{Cl}$ & 2.6 & 0.24 \\
\hline $\mathrm{Na}$ & 0.9 & 0.08 \\
\hline $\mathrm{P}$ & $6.2 \times 10^{-2}$ & $5.8 \times 10^{-3}$ \\
\hline $\mathrm{S}$ & $5.3 \times 10^{-2}$ & $4.9 \times 10^{-3}$ \\
\hline $\mathrm{Mg}$ & $4.9 \times 10^{-2}$ & $4.6 \times 10^{-3}$ \\
\hline $\mathrm{Ca}$ & $7.0 \times 10^{-3}$ & $6.5 \times 10^{-4}$ \\
\hline $\mathrm{Mn}$ & $5.1 \times 10^{-4}$ & $4.8 \times 10^{-5}$ \\
\hline $\mathrm{Al}$ & $4.9 \times 10^{-4}$ & $4.6 \times 10^{-5}$ \\
\hline Total inorganics & 6.3 & 0.59 \\
\hline Nipa sap & 152.2 & 14.20 \\
\hline
\end{tabular}

The total inorganic content of Malaysian nipa sap was determined to be $6.3 \mathrm{~g} / \mathrm{L}$, with $\mathrm{Na}, \mathrm{K}$ and $\mathrm{Cl}$ identified as the major elements. A trace amount of Mn was also found in this sap. This result contrasts with those of several previous studies reported by Tamunaidu et al. $[3,11,27]$, where no heavy metals were detected in the sap or any other parts of the nipa palm including the frond, shell, husk and leaves.

Several other palm saps have been analyzed to date and found to contain similar quantities of inorganic constituents to those found in nipa sap, such as the $\mathrm{Na}$, $\mathrm{Mg}, \mathrm{K}$ and $\mathrm{P}$ contents in saps of palmyra, coconut and date palms [28]; the $\mathrm{K}, \mathrm{Mg}, \mathrm{Ca}, \mathrm{Na}$ and $\mathrm{P}$ contents in sap of $R$. hookeri palm [29]; and the $\mathrm{Cl}, \mathrm{Ca}, \mathrm{Mg}, \mathrm{Na}$, $\mathrm{Mn}$ and $\mathrm{P}$ contents in sap of oil palm trunk [30].

The concentrations of $\mathrm{Mg}$ and $\mathrm{Ca}$ in nipa sap were 0.049 and $0.007 \mathrm{~g} / \mathrm{L}$, respectively. These values were similar to those found in palmyra, coconut and date palm saps, which are $0.051,0.022$ and $0.030 \mathrm{~g} / \mathrm{L}$ for $\mathrm{Mg}$ and $0.011,0.016$ and $0.013 \mathrm{~g} / \mathrm{L}$ for $\mathrm{Ca}$, respectively [28]. However, nipa sap has uniquely high $\mathrm{Na}$ and $\mathrm{Cl}$ contents of 0.9 and $2.6 \mathrm{~g} / \mathrm{L}$, whereas all of the other palm saps contain only $0.043-0.054 \mathrm{~g} / \mathrm{L}$ of $\mathrm{Na}$ and no $\mathrm{Cl}$.

Although the inorganic elements found in sugarcane sap [3] are also present in nipa sap, the latter has much higher $\mathrm{Na}$ and $\mathrm{Cl}$ contents. These results therefore explain the high tolerance of nipa palm to seawater salts (e.g., $\mathrm{NaCl}$ ) [31], and highlight nipa palm as the species of choice for seawater agriculture to initiate coastal rehabilitation and restore degraded wetlands [11].

\subsection{Acid Hydrolysis}

Autoclaving at $121{ }^{\circ} \mathrm{C}$ is the preferred method for sterilizing nipa sap and preventing contamination during the acetic acid fermentation process. Autoclaving can destroy all organisms and their endospores within 1520 min [32]. According to Steven et al. [33], the high temperatures used in an autoclave can result in the hydrolysis of sucrose, the extent of which is directly proportional to the hydrogen ion concentration $(\mathrm{pH})$. The combination of sucrose hydrolysis and sterilization with the acid hydrolysis of nipa sap was therefore investigated in an autoclave at $121^{\circ} \mathrm{C}$.

We investigated the addition of an acid catalyst to facilitate the hydrolysis of the sucrose present in nipa sap. We initially evaluated the use of acetic acid as a catalyst for the hydrolysis of sucrose because this acid 
is the desired product of the anaerobic fermentation of nipa sap by $M$. thermoacetica. In this way, it was envisaged that the use of acetic acid as a catalyst would avoid the need to add and subsequently remove another chemical to the formation process and product stream, respectively.

Figure 2 shows the sucrose conversions achieved using a variety of different acetic acid concentrations as a function of time. When the hydrolysis was performed without a catalyst (Figure $\mathbf{2 a}$ ), the conversion of sucrose in nipa sap reached $86 \%$ within 120 min. As shown in Table 1, the lactic acid present in nipa sap may account for its acidic $\mathrm{pH}$ and could also act as an acid catalyst for the hydrolysis of sucrose. Although the different components of nipa sap could exhibit catalytic activity towards the hydrolysis of sucrose, it was not possible to achieve the complete hydrolysis of sucrose under these conditions after $120 \mathrm{~min}$. The hydrolysis of more than $98 \%$ of the sucrose in nipa sap (corresponding to a concentration of $78.4 \mathrm{~g} / \mathrm{L}$ ) required a treatment time of at least 120 or 60 min with $3.0-5.0$ or $10-20 \mathrm{~g} / \mathrm{L}$ acetic acid, respectively. The sucrose conversion improved with increasing acetic acid concentration. However, the use of a high concentration of acetic acid could inhibit the downstream fermentation of nipa sap by $M$. thermoacetica [34], and the use a prolonged hydrolysis reaction would require much more energy for autoclaving. Hence, the use of a stronger organic acid was explored to improve the efficiency of this process.

Oxalic acid is one of the strongest of all the known organic acids, with pKa values of 1.27 and 4.28 [35]. Based on its strong acidity, oxalic acid has recently been suggested as an alternative to mineral acids such as sulfuric acid and hydrochloric acid for the hydrolysis of lignocellulosic biomass because it shows a higher catalytic efficiency $[36,37]$. With this in mind, we investigated the use of oxalic acid as catalyst for this process.

Figure $\mathbf{2} \mathbf{b}$ shows the sucrose conversions achieved for the hydrolysis of nipa sap using various oxalic acid concentrations. The results revealed that $3.0 \mathrm{~g} / \mathrm{L}$ of oxalic acid could hydrolyze $98 \%$ of the sucrose in nipa sap within $20 \mathrm{~min}$, corresponding to the time required for the complete sterilization of nipa sap. These hydrolysis conditions are therefore very practical. The results also showed that the speed of the sucrose conversion increased with the augmentation of the oxalic acid concentration, which can be explained in terms of the associated decrease in the $\mathrm{pH}$ of the nipa sap, as shown in Table 2. Based on these results, oxalic acid was selected as the optimum catalyst for the hydrolysis of sucrose because it allowed for a considerable decrease in the treatment time.

(a) Acetic acid

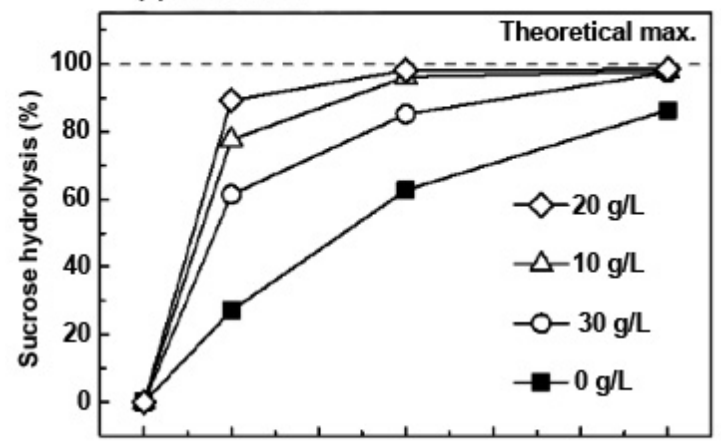

(b) Oxalic acid

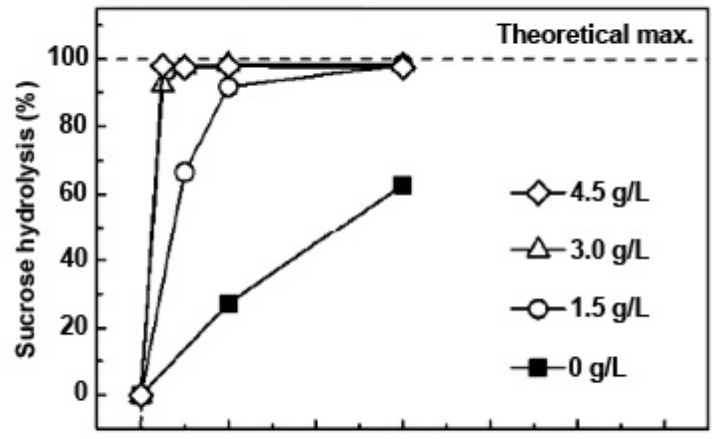

(c) Invertase

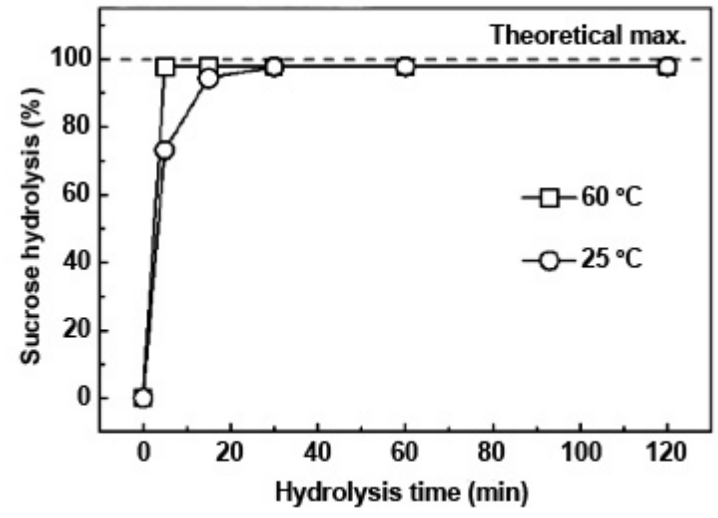

Figure 2: Hydrolysis of the sucrose in nipa sap to glucose and fructose at (a) $121{ }^{\circ} \mathrm{C}$ in an autoclave under various acetic acid concentrations (0, 3.0, 10 and $20 \mathrm{~g} / \mathrm{L})$; (b) $121^{\circ} \mathrm{C}$ in an autoclave under various oxalic acid concentrations $(0$, $1.5,3.0$ and $4.5 \mathrm{~g} / \mathrm{L}$ ); and (c) 25 and $60{ }^{\circ} \mathrm{C}$ using $3.92 \mathrm{v} / \mathrm{v} \%$ invertase.

We also investigated the hydrolysis of the sucrose in nipa sap with hydrochloric acid, a strong mineral acid, and compared the results with those of acetic acid and oxalic acid. As shown in Table 2, hydrochloric acid showed a higher level of activity towards the hydrolysis of sucrose compared with oxalic acid and acetic acid. However, the glucose and fructose yields (92\%) achieved following the treatment of nipa sap with $3.0 \mathrm{~g} / \mathrm{L}$ of 
Table 2: Evaluation of Different Catalysts Used for the Hydrolysis of Sucrose in Nipa Sap to Glucose and Fructose and the Resulting pH Values

\begin{tabular}{|c|c|c|c|c|c|}
\hline \multirow{2}{*}{ Catalyst } & \multirow{2}{*}{$\begin{array}{l}\text { Hydrolysis Time } \\
\text { (min) }\end{array}$} & \multirow{2}{*}{$\begin{array}{c}\text { Sucrose } \\
\text { Conversion (\%) }\end{array}$} & \multirow{2}{*}{$\begin{array}{c}\text { Glucose and } \\
\text { Fructose Yield (\%) }\end{array}$} & \multicolumn{2}{|c|}{$\mathrm{pH}$} \\
\hline & & & & Before Hydrolysis & After Hydrolysis \\
\hline \multirow{4}{*}{ No catalyst } & 20 & 27 & 25 & \multirow{4}{*}{4.37} & 4.23 \\
\hline & 60 & 63 & 61 & & 4.14 \\
\hline & 120 & 86 & 83 & & 4.04 \\
\hline & 180 & 94 & 87 & & 3.97 \\
\hline \multirow{4}{*}{ Acetic acid, $3.0 \mathrm{~g} / \mathrm{L}$} & 20 & 61 & 61 & \multirow{4}{*}{3.92} & 3.87 \\
\hline & 60 & 85 & 82 & & 3.83 \\
\hline & 120 & 98 & 96 & & 3.80 \\
\hline & 180 & 98 & 95 & & 3.76 \\
\hline \multirow{4}{*}{ Acetic acid, $10 \mathrm{~g} / \mathrm{L}$} & 20 & 78 & 77 & \multirow{4}{*}{3.65} & 3.62 \\
\hline & 60 & 96 & 93 & & 3.58 \\
\hline & 120 & 98 & 93 & & 3.57 \\
\hline & 180 & 99 & 86 & & 3.56 \\
\hline \multirow{4}{*}{ Oxalic acid, $3.0 \mathrm{~g} / \mathrm{L}$} & 5 & 92 & 92 & \multirow{4}{*}{2.67} & - \\
\hline & 10 & 98 & 98 & & - \\
\hline & 20 & 98 & 98 & & 2.73 \\
\hline & 60 & 98 & 94 & & 2.73 \\
\hline \multirow{4}{*}{ Oxalic acid, $4.5 \mathrm{~g} / \mathrm{L}$} & 5 & 98 & 98 & \multirow{4}{*}{2.10} & - \\
\hline & 10 & 97 & 96 & & - \\
\hline & 20 & 98 & 94 & & 2.16 \\
\hline & 60 & 98 & 91 & & 2.17 \\
\hline \multirow{2}{*}{$\mathrm{HCl}, 3.0 \mathrm{~g} / \mathrm{L}$} & 5 & 96 & 92 & \multirow{2}{*}{-} & - \\
\hline & 10 & 94 & 87 & & - \\
\hline \multirow{3}{*}{ Invertase, $3.92 \mathrm{v} / \mathrm{v} \%$} & 5 & 73 & 73 & \multirow{3}{*}{-} & - \\
\hline & 15 & 95 & 95 & & - \\
\hline & 30 & 98 & 98 & & - \\
\hline
\end{tabular}

hydrochloric acid for 10 min were inferior to the sucrose conversion (98\%), which indicated that hydrochloric acid could be triggering the decomposition of the monosugars produced during this process. Hydrochloric acid is well known to be highly corrosive [38], and would therefore need to be neutralized or removed from the mixture prior to the acetic acid fermentation process. Based on the disadvantages associated with the use of hydrochloric acid, we concluded that this acid was unsuitable for the hydrolysis of sucrose compared with oxalic acid.

To clarify the kinetics of the acid hydrolysis reaction in the autoclave at $121{ }^{\circ} \mathrm{C}$, it was assumed that the reaction followed first order kinetics as a function of the initial $\left(\mathrm{C}_{0}\right)$ and remaining $\left(\mathrm{C}_{\mathrm{t}}\right)$ sucrose concentrations over time $(\mathrm{t})$ :

$$
\ln \frac{\mathrm{C}_{\mathrm{t}}}{\mathrm{C}_{0}}=-\mathrm{kt}
$$

Figure 3 shows the effects of various acetic acid and oxalic acid concentrations on the reactions kinetics for the hydrolysis of sucrose. When the hydrolysis was conducted without catalyst $(0 \mathrm{~g} / \mathrm{L})$, the reaction showed good linearity and therefore appeared to obey first order kinetics. At higher catalyst concentrations, the hydrolysis reactions showed reasonable linearity for the first few min, but not for longer treatment times (e.g., 60 min for $3.0 \mathrm{~g} / \mathrm{L}$ of acetic acid and $10 \mathrm{~min}$ for $3.0 \mathrm{~g} / \mathrm{L}$ of oxalic acid). The lack of linearity in these cases can be explained in terms of the side reactions occurring under the high temperature conditions, as presented earlier. According to Khajavi et al. [39], the hydrolysis reactions of monosugars at high temperatures do not obey first order kinetics because of the acceleration in the rates of the hydrolysis and decomposition reactions with decreasing $\mathrm{pH}$ during the hydrolysis. In the case of the hydrolysis of nipa sap without a catalyst, the hydrolysis of sucrose followed first order kinetics, most likely as a result of the relatively slow reaction rate. 
(a) Acetic acid

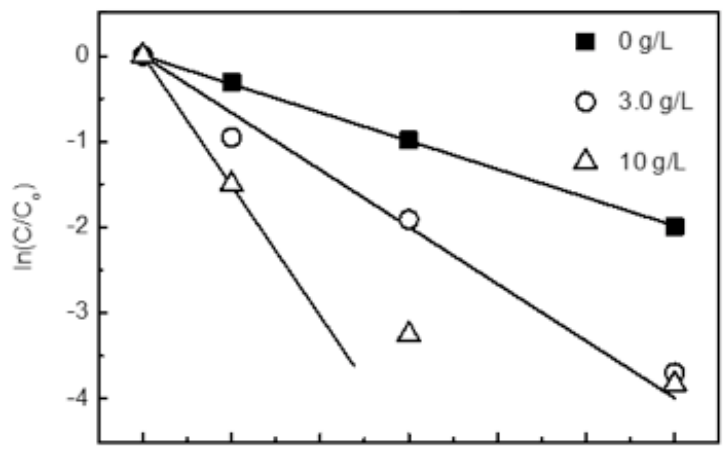

(b) Oxalic acid

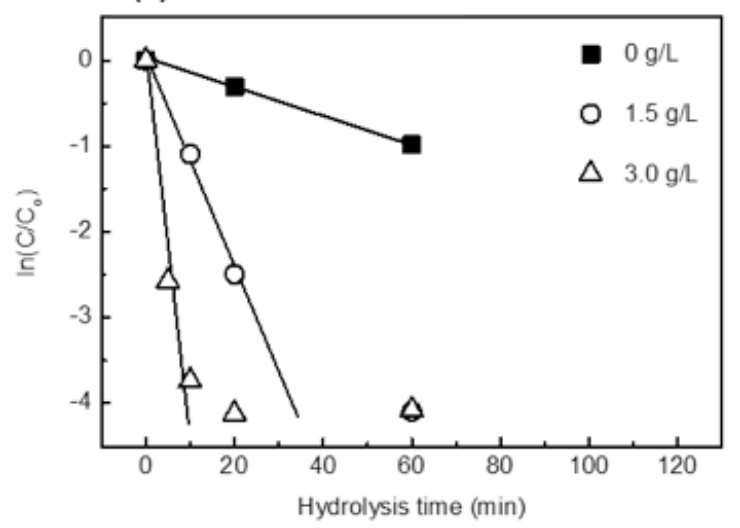

Figure 3: Relationship between the $\mathrm{C} / \mathrm{C}_{\mathrm{o}}$ ratio of sucrose and the treatment time for the hydrolysis of sucrose in nipa sap by (a) various acetic acid concentrations ( $0,3.0,10$ and $20 \mathrm{~g} / \mathrm{L})$, and (b) various oxalic acid concentrations (0, 1.5 and 3.0 $\mathrm{g} / \mathrm{L})$.

\subsection{Enzymatic Hydrolysis}

To compare the acid hydrolysis with an enzymatic hydrolysis, we investigated the pretreatment of nipa sap with invertase. As shown in Figure 2c, invertase proved to be an effective catalyst for the hydrolysis of sucrose even at room temperature, with $3.92 \mathrm{v} / \mathrm{v} \%$ invertase hydrolyzing $98 \%$ of the sucrose within $30 \mathrm{~min}$ at $25{ }^{\circ} \mathrm{C}$ and only $5 \mathrm{~min}$ at $60{ }^{\circ} \mathrm{C}$. Both of these temperatures could therefore be used for this process. In addition, the optimum temperature for the fermentation of acetic acid by $M$. thermoacetica is $60{ }^{\circ} \mathrm{C}$ [19]. This result therefore indicated that it could be possible to perform the enzymatic hydrolysis together with the fermentation of acetic acid at $60^{\circ} \mathrm{C}$.

\subsection{Comparison of the Different Catalysts}

Table 2 shows the different catalysts used for the hydrolysis of the sucrose in nipa sap to glucose and fructose, and the resulting $\mathrm{pH}$ values. The glucose and fructose yields increased during the initial phase of the hydrolysis, but decreased with prolonged treatment periods and higher catalyst concentrations. For instance, the glucose and fructose yields for the hydrolysis of nipa sap with $3.0 \mathrm{~g} / \mathrm{L}$ of oxalic acid decreased from 98 to $94 \%$ when the hydrolysis treatment time was extended from 10 to $60 \mathrm{~min}$. Furthermore, increasing the concentration of oxalic acid from 3.0 to $4.5 \mathrm{~g} / \mathrm{L}$ led to a reduction in the yields of glucose and fructose to $91 \%$ after $60 \mathrm{~min}$. For an ideal hydrolysis reaction, the glucose and fructose yields should be equal to the sucrose conversion. However, prolonging the treatment time in the autoclave led to a slight decrease in the total sugar content of the nipa sap. Previous studies involving superheated water have shown that monosaccharides can decompose to give other compounds, such as 5-hydroxymethylfurufral (5-HMF), furfural and organic acids (e.g., formic acid, levulinic acid, acetic acid and lactic acid) [39-41] or isomerize to give different monosugars [42]. According to Nakamura et al. [22], organic compounds such as 5-HMF, furfural, lactic acid and formic acid can be fermented by $M$. thermoacetica to acetic acid. Consequently, even if these decomposed products were present in the nipa sap hydrolyzate, they would be fermented to acetic acid by M. thermoacetica.

The results presented above for the acid-catalyzed hydrolysis of the sucrose in nipa sap revealed that oxalic acid was more effective than hydrochloric acid because the latter led to the rapid decomposition of the monosugar products. Furthermore, acetic acid was found to be too weak to achieve the rapid and complete hydrolysis of sucrose. It is noteworthy that the pretreatment of nipa sap with oxalic acid has been reported to be less toxic to subsequent biological steps than acetic or sulfuric acids, and does not produce poisonous odors [35]. The optimal conditions for the acid-catalyzed hydrolysis of the sucrose in nipa sap were determined to be $3.0 \mathrm{~g} / \mathrm{L}$ of oxalic acid within $20 \mathrm{~min}$, which gave $98 \%$ yields of glucose and fructose. In the case of invertase, the glucose and fructose yields were equivalent to the sucrose conversion because of the relatively low temperature required for the hydrolysis ( 25 and $60^{\circ} \mathrm{C}$ ).

These results revealed that the hydrolytic activities of oxalic acid and invertase were similarly good. Table 3 provides a comparison of oxalic acid and invertase in terms of their price and energy consumption characteristics for the hydrolysis of nipa sap.

Given that the process configurations for the two different types of hydrolysis reaction were different, as shown in Figure 1, the different units of these processes 
would have different energy demands. In the case of the acid-catalyzed hydrolysis, the nipa sap was simultaneously sterilized and hydrolyzed in the same unit. In this way, the heat generated during the exothermic hydrolysis of sucrose led to an increase in the temperature of the nipa sap inside the autoclave. Consequently, the autoclave consumed heat energy at a rate of $94.3 \mathrm{MJ} / \mathrm{h}$. However, in the case of the enzymatic hydrolysis, the hydrolysis and sterilization steps were conducted in different units. The hydrolysis step therefore required cooling energy to remove the excess heat formed by the reaction, whereas the sterilization required much greater heat energy than that required for the acid-catalyzed hydrolysis because the heat of the hydrolysis reaction was not recovered. The results presented in Table 3 show that the hydrolysis and sterilization steps consumed energy at rate of -1.9 and $100.6 \mathrm{MJ} / \mathrm{h}$, respectively, for the enzymatic hydrolysis. The negative value in this case shows that heat removal was required.

Table 3: Comparison of Oxalic Acid and Invertase in Terms of their Price and Energy Consumption for the Production of Acetic Acid from Nipa Sap

\begin{tabular}{|c|c|c|}
\hline & $\begin{array}{c}\text { Acid } \\
\text { Hydrolysis }\end{array}$ & $\begin{array}{c}\text { Enzymatic } \\
\text { Hydrolysis }\end{array}$ \\
\hline \hline Catalyst & $\begin{array}{c}\text { Oxalic Acid } \\
\text { Dihydrate }\end{array}$ & $\begin{array}{c}\text { Invertase } \\
\text { Solution }\end{array}$ \\
\hline Unit price $(\$ / \mathrm{kg})$ & 40.0 & $2,880.0$ \\
\hline Flow rate $(\mathrm{kg} / \mathrm{h})$ & 2.9 & 31.2 \\
\hline Cost $(\$ / \mathrm{h})$ & 116.0 & $89,856.0$ \\
\hline Energy Consumption & \multicolumn{2}{|c|}{} \\
\hline Pump (MJ/h) & 0.1 & 0.1 \\
\hline Sterilization (MJ/h) & $94.3^{2}$ & 100.6 \\
\hline Hydrolysis (MJ/h) & - & -1.9 \\
\hline Total hydrolysis stage $(\mathrm{MJ} / \mathrm{h})$ & 94.4 & 100.7 \\
\hline \multicolumn{2}{|c|}{} & Acetic Acid Fermentation \\
\hline Fermentor (MJ/h) & 284.3 & 283.0 \\
\hline Total process $(\mathrm{MJ} / \mathrm{h})$ & 378.7 & 383.7 \\
\hline
\end{tabular}

${ }^{1}$ These prices were provided by Wako Pure Chemical Industries Ltd. [43,44].

${ }^{2}$ Energy consumption data for the acid hydrolysis and sterilization (autoclave) steps.

The oxalic acid- and invertase-catalyzed hydrolysis steps consumed 94.4 and $100.7 \mathrm{MJ} / \mathrm{h}$ of energy, respectively. Consideration of the whole process including the fermentation step after the acid- and enzymecatalyzed hydrolysis reactions revealed that their total energy consumptions were 378.7 and $383.7 \mathrm{MJ} / \mathrm{h}$, respectively. There were therefore no major differences in the energy consumptions of these two hydrolysis methods. However, as shown in Table 3, invertase is more expensive than oxalic acid (approximately 775fold more expensive). Based on these considerations, the oxalic acid-catalyzed hydrolysis of nipa sap represents the most economically efficient of these two methods. The effects of these two catalysts on the subsequent acetic acid fermentation process will be described in the next section.

\subsection{Acetic Acid Fermentation of Hydrolyzed Nipa Sap by $M$. thermoacetica}

Nipa sap was hydrolyzed in the presence of $3.0 \mathrm{~g} / \mathrm{L}$ of oxalic acid at $121{ }^{\circ} \mathrm{C}$ for $20 \mathrm{~min}$ or $3.92 \mathrm{v} / \mathrm{v} \%$ invertase at $25{ }^{\circ} \mathrm{C}$ for $30 \mathrm{~min}$. The resulting hydrolyzed mixtures were used as substrates for acetic acid with $M$. thermoacetica. Like all known acetogens, the activity of $M$. thermoacetica may be inhibited by high concentrations of acetate ions or protons $[45,46]$. With this in mind, the total organic concentration of the hydrolyzed nipa sap used in the acetic acid fermentation broth in the current study was decreased to approximately $10 \mathrm{~g} / \mathrm{L}$.

Figure 4a shows the batch fermentation profiles for the consumption of glucose and fructose, as well as the production of acetic acid for the nipa sap hydrolyzed by oxalic acid. The results revealed that the substrates had completely fermented after $72 \mathrm{~h}$. However, the acetic acid concentration only increased slightly during the first $24 \mathrm{~h}$, before rapidly increasing to $6.11 \mathrm{~g} / \mathrm{L}$ over the next $24 \mathrm{~h}$ with the highest rate of acetic acid production reaching $0.24 \mathrm{~g} / \mathrm{L} / \mathrm{h}$. After this point, the production of acetic acid occurred at a much slower rate of $0.02 \mathrm{~g} / \mathrm{L} / \mathrm{h}$ and reached its highest concentration of $10.03 \mathrm{~g} / \mathrm{L}$ at $217 \mathrm{~h}$. It is noteworthy that the lactic acid and ethanol found in nipa sap may be fermented to acetic acid by $M$. thermoacetica [47], suggesting that these compounds could also be making a small contribution to the final acetic acid concentration.

Furthermore, oxalic acid was not detected in the fermentation broth after $72 \mathrm{~h}$, which indicated that this material was a substrate for $M$. thermoacetica. According to Daniel et al. [23], oxalic acid not only supports the growth of $M$. thermoacetica cells in the absence of supplemental $\mathrm{CO}_{2}$, but is also converted to acetic acid by the bacterium according to the following reaction:

$4^{-} \mathrm{OOC}-\mathrm{COO}^{-}+5 \mathrm{H}_{2} \mathrm{O} \rightarrow \mathrm{CH}_{3} \mathrm{COO}^{-}+6 \mathrm{HCO}_{3}{ }^{-}+\mathrm{HO}^{-}$

This equation shows that 4 moles of oxalic acid can be converted to 1 mole of acetic acid. A theoretical 
(a) Hydrolyzed by oxalic acid

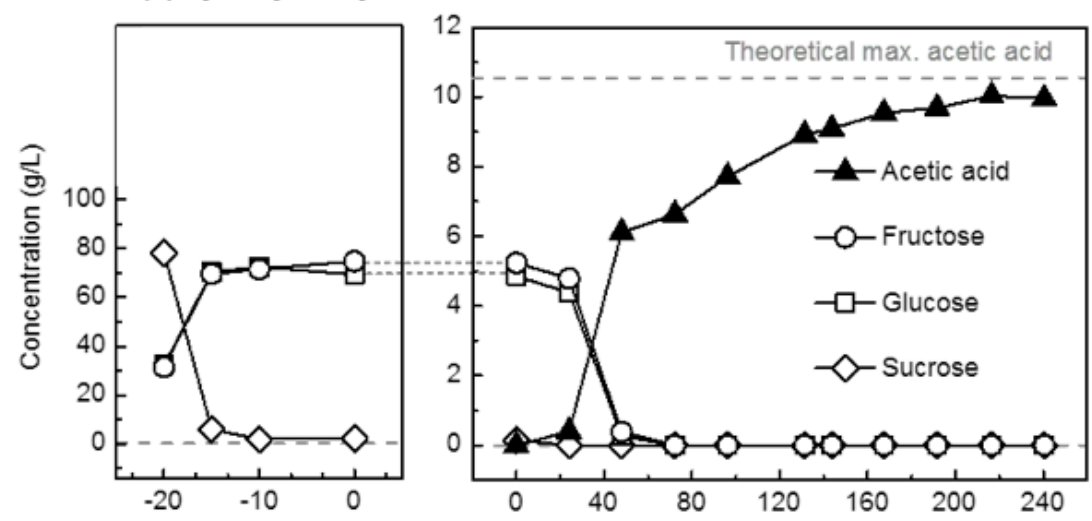

(b) Hydrolyzed by invertase

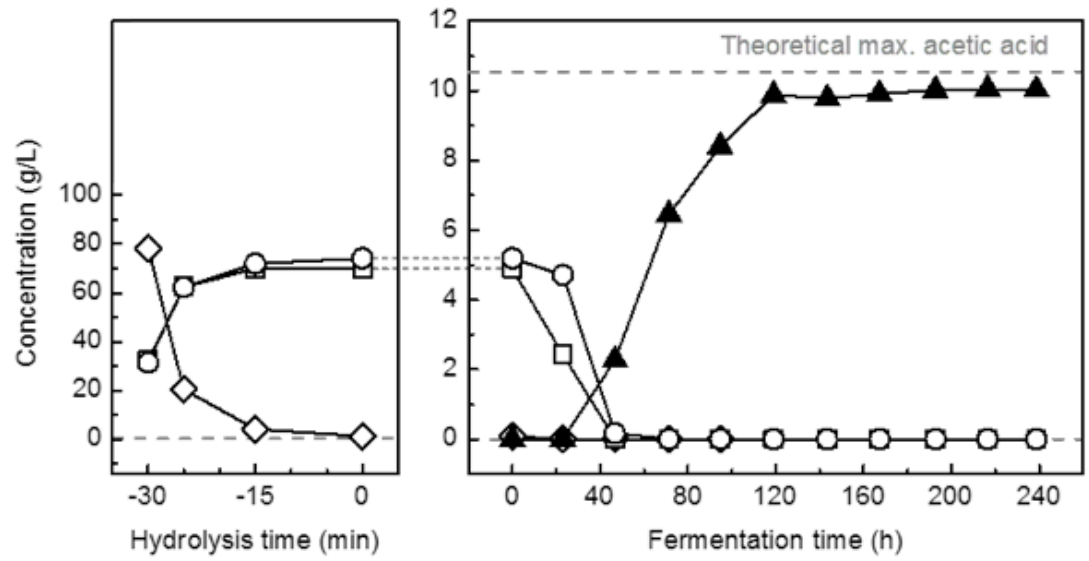

Figure 4: Batch fermentation profiles for the production of acetic acid by $M$. thermoacetica from nipa sap following the hydrolysis of the sap with (a) $3 \mathrm{~g} / \mathrm{L}$ of oxalic acid at $121^{\circ} \mathrm{C}$ or (b) $3.92 \mathrm{v} / \mathrm{v} \%$ invertase at $25^{\circ} \mathrm{C}$.

maximum of $0.04 \mathrm{~g} / \mathrm{L}$ of acetic acid could therefore be produced from a fermentation broth containing $0.21 \mathrm{~g} / \mathrm{L}$ of oxalic acid.

The acetic acid yield achieved following the hydrolysis of nipa sap with invertase (Figure 4b) was similar to the yield achieved using oxalic acid as a catalyst for the hydrolysis. The results revealed that all of the glucose and fructose had been completely consumed within $71 \mathrm{~h}$. It is noteworthy, however, that a lag period was observed in the production of acetic acid for the first $23 \mathrm{~h}$, after which time the acetic acid concentration increased considerably to $9.88 \mathrm{~g} / \mathrm{L}$ over $96 \mathrm{~h}$, with an average acetic acid production rate of $0.10 \mathrm{~g} / \mathrm{L} / \mathrm{h}$. The maximum acetic acid concentration obtained from $10.22 \mathrm{~g} / \mathrm{L}$ of organic compounds in the original nipa sap $(5.49 \mathrm{~g} / \mathrm{L}$ sucrose, $2.26 \mathrm{~g} / \mathrm{L}$ glucose, $2.20 \mathrm{~g} / \mathrm{L}$ fructose, $0.15 \mathrm{~g} / \mathrm{L}$ lactic acid and $0.12 \mathrm{~g} / \mathrm{L}$ ethanol) was $10.05 \mathrm{~g} / \mathrm{L}$ at $216 \mathrm{~h}$.

Neither of the two catalysts evaluated in the hydrolysis step showed any inhibitory effects towards the subsequent fermentation step with $M$. thermoacetica and gave similar acetic acid yields of approximately 10 $\mathrm{g} / \mathrm{L}$. Research towards the development of a fed-batch fermentation process based on these results is currently underway in our laboratory in an attempt to improve the product concentration.

A comparison of the conversion efficiencies of oxalic acid and invertase for the production of acetic acid revealed that they both gave similarly high values $(98 \%)$, although the fermentation was slightly faster for the nipa sap hydrolyzed with invertase. It is important to mention that the traditional vinegar production processes used in the Philippines typically produce as little as $4.5-5.5 \%$ acetic acid from $15-22 \%$ nipa sap because of the $\mathrm{CO}_{2}$ generated during the fermentation process [8]. These traditional processes are much less efficient than the process developed in this study because they only deliver an average conversion efficiency of $27 \%$. The conversion efficiency of the new process described in this study is 3.6 times greater than that of the traditional methods at $98 \%$. The hydrolytic pretreatment of nipa sap followed by its anaerobic fermentation with $M$. thermoacetica therefore repre- 
sents a considerable improvement in the production of acetic acid from nipa sap compared with traditional methods.

The acetic acid generated using our new method could be used directly as vinegar, solvent or preservative in the food industry $[15,16,48]$. This material could also be used as a key intermediate for the production of other value-added products, such as renewable fine chemicals, pharmaceutical products, plastics, synthetic fibers [16], deicers [49], ethanol fuel via its hydrogenation over a metal catalyst [50-52] and microbial oils for biodiesel production [53].

\section{CONCLUSIONS}

In this study, we have investigated the hydrolysis and fermentability of nipa sap to give acetic acid. The results revealed that acetic acid acted as an extremely weak catalyst for the hydrolysis step, whereas hydrochloric acid acted as an extremely strong acid catalyst. Oxalic acid and invertase both showed good hydrolytic activities and similar energy requirements for the hydrolysis step, but oxalic acid was determined to be advantageous in terms of its price. Furthermore, oxalic acid may be fermented by $M$. thermoacetica, thereby avoiding the need to separate the catalyst after the fermentation process. The solution generated following the hydrolysis of nipa sap with oxalic acid or invertase was efficiently fermented to acetic acid by $M$. thermoacetica. Compared with traditional methods for the production of vinegar, much higher conversion efficiencies to acetic acid were obtained from nipa sap using the conditions developed in this study. The findings of this study demonstrate that nipa sap and several other sucrose-containing biomass materials can be readily used for the production of acetic acid by acid- or enzyme-catalyzed hydrolysis, followed by fermentation with $M$. thermoacetica, without releasing any $\mathrm{CO}_{2}$. It is therefore envisaged that this process will not only enhance the economic value of nipa palm in rural coastal communities, but also mitigate environmental burdens associated with this material.

\section{ACKNOWLEDGMENTS}

This work was supported by the Japan Science and Technology Agency (JST) under the Advanced Low Carbon Technology Research and Development Program (ALCA), for which the authors are extremely grateful. The first author would like to acknowledge the financial support received from JICA under the AUN/SEED-Net Project for his PhD study. The second author is grateful to the Thailand Research Fund (TRF) for financially supporting his post-doctoral study. Last but not least, the authors would like to thank Dr Pramila Tamunaidu from Malaysia-Japan International Institute of Technology, Universiti Teknologi Malaysia for providing the nipa sap samples used in this study.

\section{REFERENCES}

[1] Hamilton LS, Murphy $\mathrm{DH}$. Use and management of nipa palm (Nypa fruticans, Arecaceae): A review. Econ Bot. 1988; 42(2): 206-13.

http://dx.doi.org/10.1007/BF02858921

[2] Päivöke AEA. Nypa fruticans Wurmb. In: Flach M, Rumawas F, Eds. Plants Yielding Non-Seed Carbohydrates. Plant Resources of South-East Asia No. 9. Leiden, The Netherlands: Backhuys Publisher 1996; pp. 133-37.

[3] Tamunaidu P, Saka S. Comparative study of nutrient supplements and natural inorganic components in ethanolic fermentation of nipa sap. J Jpn Inst Energy 2013; 92(2): 181-86. http://dx.doi.org/10.3775/jie.92.181

[4] Päivöke AEA. Tapping practices and sap yields of the nipa palm (Nypa fruticans) in Papua New Guinea. Agric Ecosyst Environ. 1985; 13(1): 59-72.

http://dx.doi.org/10.1016/0167-8809(85)90101-X

[5] Bamroongrugsa N, Purintavarakul C, Kato S, Stargardt J. Production of sugar-beating sap from nipa palm in Pak Phanang Basin, Southern Thailand. Bull Soc Sea Water Sci Jpn. 2004; 58(3): 304-12.

[6] Tamunaidu $P$, Saka S. On-site sugar analysis and pretreatment of nipa saps. In: Yao T, Ed. Zero-Carbon Energy Kyoto 2011. Green Energy and Technology. Japan: Springer 2012; pp. 121-26.

[7] Baba S, Chan HT, Aksornkoae S. Traditional non-wood products. In: Chan HT, Ed. Useful products from mangrove and other coastal plants. ISME Mangrove Educational Book Series No. 3. Japan: ISME and ITTO 2013; pp. 39-76.

[8] Lim-Castillo P. Traditional Philippine vinegars and their role in shaping the culinary culture. In: Hosking R, Ed. Authenticity in the Kitchen: Proceedings of the Oxford Symposium on Food and Cookery. UK: Oxford Symposium 2006; pp. 295306.

[9] Udofia S, Udo E. Local knowledge of utilization of nipa palm (Nypa fruticans, Wurmb) in the coastal areas of Akwa Ibom state, Nigeria. Glob J Agric Sci. 2005; 4(1): 33-40.

http://dx.doi.org/10.4314/gjass.v4i1.2252

[10] Tamunaidu P, Kakihira T, Miyasaka H, Saka S. Prospect of nipa sap for bioethanol production. In: Yao T, Ed. ZeroCarbon Energy Kyoto 2010. Green Energy and Technology. Japan: Springer 2011; pp. 159-64.

[11] Tamunaidu P, Matsui N, Okimori Y, Saka S. Nipa (Nypa fruticans) sap as a potential feedstock for ethanol production. Biomass Bioenergy 2013; 52: 96-102. http://dx.doi.org/10.1016/j.biombioe.2013.03.005

[12] Hidayat IW. Natural production potency of nipa (Nypa fruticans) sap as production commodity for bioethanol. Pros Sem Nas Masy Biodiv Indon. 2015; 1(1): 109-13.

http://dx.doi.org/10.13057/psnmbi/m010118

[13] Marris E. Sugar cane and ethanol: Drink the best and drive the rest. Nature 2006; 444(7120): 670-72.

http://dx.doi.org/10.1038/444670a

[14] Cheung H, Tanke RS, Torrence GP. Acetic acid. Ullmann's Encyclopedia of Industrial Chemistry. Weinheim: Wiley-VCH Verlag GmbH \& Co. KGaA 2000; pp. 209-38.

http://dx.doi.org/10.1002/14356007.a01_045 
[15] ljmker HM, Gramblička M, Kersten SRA, van der Ham AGJ, Schuur B. Acetic acid extraction from aqueous solutions using fatty acids. Sep Purif Technol. 2014; 125: 256-63.

http://dx.doi.org/10.1016/j.seppur.2014.01.050

[16] Yoneda N, Kusano S, Yasui M, Pujado P, Wilcher S. Recent advances in processes and catalysts for the production of acetic acid. Appl Catal A 2001; 221(1-2): 253-65.

http://dx.doi.org/10.1016/S0926-860X(01)00800-6

[17] Päivöke AEA, Adams MR, Twiddy DR. Nipa palm vinegar in Papua New Guinea. Process Biochem. 1984; 19(3): 84-87.

[18] Kondo T, Kondo M. Efficient production of acetic acid from glucose in a mixed culture of Zymomonas mobilis and Acetobacter sp. J Ferment Bioeng. 1996; 81(1): 42-46.

http://dx.doi.org/10.1016/0922-338X(96)83118-7

[19] Fontaine FE, Peterson WH, McCoy E, Johnson MJ, Ritter GJ. A new type of glucose fermentation by Clostridium thermoaceticum. J Bacteriol. 1942; 43(6): 701-15.

[20] Koesnandar A, Nishio N, Nagai S. Effects of trace metal ions on the growth, homoacetogenesis and corrinoid production by Clostridium thermoaceticum. J Ferment Bioeng. 1991; 71(3): 181-85.

http://dx.doi.org/10.1016/0922-338X(91)90106-Q

[21] Andreesen JR, Schaupp A, Neurauter C, Brown A, Ljungdahl LG. Fermentation of glucose, fructose, and xylose by Clostridium thermoaceticum: Effect of metals on growth yield, enzymes, and the synthesis of acetate from $\mathrm{CO}_{2} . \mathrm{J}$ Bacteriol. 1973; 114(2): 743-51.

[22] Nakamura Y, Miyafuji H, Kawamoto H, Saka S. Acetic acid fermentability with Clostridium thermoaceticum and Clostridium thermocellum of standard compounds found in beech wood as produced in hot-compressed water. J Wood Sci. 2011; 57(4): 331-37.

http://dx.doi.org/10.1007/s10086-010-1169-3

[23] Daniel SL, Drake HL. Oxalate- and glyoxylate-dependent growth and acetogenesis by Clostridium thermoaceticum. Appl Environ Microbiol. 1993; 59(9): 3062-69.

[24] Kita A, Iwasaki Y, Sakai S, Okuto S, Takaoka K, Suzuki T, et al. Development of genetic transformation and heterologous expression system in carboxydotrophic thermophilic acetogen Moorella thermoacetica. J Biosci Bioeng. 2013; 115(4): 34752.

http://dx.doi.org/10.1016/j.jbiosc.2012.10.013

[25] Rabemanolontsoa H, Yoshimizu K, Saka S. High conversion efficiency of Japanese cedar hydrolyzates into acetic acid by co-culture of Clostridium thermoaceticum and Clostridium thermocellum. J Chem Technol Biotechnol. 2015.

http://dx.doi.org/10.1002/jctb.4679

[26] Nur Aimi R, Abu Bakar F, Dzulkifly MH. Determination of volatile compounds in fresh and fermented nipa sap (Nypa fruticans) using static headspace gas chromatography-mass spectrometry (GC-MS). Int Food Res J. 2013; 20(1): 369-76.

[27] Tamunaidu $P$, Saka S. Chemical characterization of various parts of nipa palm (Nypa fruticans). Ind Crop Prod. 2011; 34(3): 1423-28.

http://dx.doi.org/10.1016/j.indcrop.2011.04.020

[28] Barh D, Mazumdar B. Comparative nutritive values of palm saps before and after their partial fermentation and effective use of wild date (Phoenix sylvestris Roxb.) sap in treatment of anemia. Res J Med Medical Sci. 2008; 3(2): 173-76.

[29] Obahiagbon F, Osagie A. Sugar and macrominerals composition of sap produced by Raphia hookeri palms. Afr J Biotechnol. 2007; 6(6): 744-50.

[30] Kosugi A, Tanaka R, Magara K, Murata Y, Arai T, Sulaiman $\mathrm{O}$, et al. Ethanol and lactic acid production using sap squeezed from old oil palm trunks felled for replanting. J Biosci Bioeng. 2010; 110(3): 322-25.

http://dx.doi.org/10.1016/j.jbiosc.2010.03.001
Dickson AG, Goyet C. Physical and thermodynamic data. In: Dickson AG, Goyet C, Eds. Handbook of Methods for the Analysis of the Various Parameters of the Carbon Dioxide System in Sea Water. Washington, DC: ORNL/CDIAC-74, U. S. Department of Energy 1994; pp. 166-87.

[32] Sumbali G, Mehrotra RS. Control of microorganisms-sterilisation and disinfection. In: Snigdha S, Upadhyay R, Dey D, Eds. Principles of Microbiology. New Delhi: Tata McGraw Hill Education Private Limited 2009; pp. 125-52.

[33] Wann S, Veazey R, Kaphammer J. Activated charcoal does not catalyze sucrose hydrolysis in tissue culture media during autoclaving. Plant Cell Tiss Org Cult. 1997; 50(3): 221-24. http://dx.doi.org/10.1023/A:1005947008637

[34] Wang G, Wang DIC. Elucidation of growth inhibition and acetic acid production by Clostridium thermoaceticum. Appl Environ Microbiol. 1984; 47(2): 294-98.

[35] Lee J-W, Rodrigues RCLB, Jeffries TW. Simultaneous saccharification and ethanol fermentation of oxalic acid pretreated corncob assessed with response surface methodology. Bioresour Technol. 2009; 100(24): 6307-11. http://dx.doi.org/10.1016/j.biortech.2009.06.088

[36] Zhang T, Kumar R, Wyman CE. Sugar yields from dilute oxalic acid pretreatment of maple wood compared to those with other dilute acids and hot water. Carbohydr Polym. 2013; 92(1): 334-44.

http://dx.doi.org/10.1016/j.carbpol.2012.09.070

[37] Lee J-W, Houtman CJ, Kim H-Y, Choi I-G, Jeffries TW. Scale-up study of oxalic acid pretreatment of agricultural lignocellulosic biomass for the production of bioethanol. Bioresour Technol. 2011; 102(16): 7451-56.

http://dx.doi.org/10.1016/j.biortech.2011.05.022

[38] Craig BD, Anderson DS. Hydrochloric acid. In: Craig BD, Anderson DS, Eds. Handbook of Corrosion Data. Materials Park, Ohio: ASM Int. 1994; pp. 405-36.

[39] Haghighat Khajavi S, Kimura Y, Oomori T, Matsuno R, Adachi S. Kinetics on sucrose decomposition in subcritical water. LWT Food Sci Technol. 2005; 38(3): 297-302.

http://dx.doi.org/10.1016/j.Iwt.2004.06.005

[40] Antal Jr MJ, Mok WSL, Richards GN. Mechanism of formation of 5-(hydroxymethyl)-2-furaldehyde from D-fructose and sucrose. Carbohydr Res. 1990; 199(1): 91-109.

http://dx.doi.org/10.1016/0008-6215(90)84096-D

[41] Kabyemela BM, Adschiri T, Malaluan RM, Arai K. Glucose and fructose decomposition in subcritical and supercritical water: Detailed reaction pathway, mechanisms, and kinetics. Ind Eng Chem Res. 1999; 38(8): 2888-95.

http://dx.doi.org/10.1021/ie9806390

[42] Usuki C, Kimura $Y$, Adachi S. Isomerization of hexoses in subcritical water. Food Sci Technol Res. 2007; 13(3): 205-09. http://dx.doi.org/10.3136/fstr.13.205

[43] Wako Pure Chemical Industries Ltd. 2015 Oxalic Acid Dihydrate. http://www.e-reagent.com/uh/Shs.do?now=1449036937 311. (accessed November 26, 2015).

[44] Wako Pure Chemical Industries Ltd. 2015 Invertase, Solution, from Yeast. http://www.e-reagent.com/uh/Shs.do?now= 1449036981255. (accessed November 26, 2015).

[45] Baronofsky JJ, Schreurs WJA, Kashket ER. Uncoupling by acetic acid limits growth of and acetogenesis by Clostridium thermoaceticum. Appl Environ Microbiol. 1984; 48(6): 113439.

[46] Drake HL, Gößner AS, Daniel SL. Old acetogens, new light. Ann NY Acad Sci. 2008; 1125(1): 100-28.

http://dx.doi.org/10.1196/annals.1419.016

[47] Drake HL, Daniel SL. Physiology of the thermophilic acetogen Moorella thermoacetica. Res Microbiol. 2004; 155(10): 869-83.

http://dx.doi.org/10.1016/j.resmic.2004.10.002 
[48] Lück E, von Rymon Lipinski G-W. Foods, 3. Food additives. Ullmann's Encyclopedia of Industrial Chemistry. Weinheim: Wiley-VCH Verlag GmbH \& Co. KGaA 2000; pp. 671-92.

[49] Vitaliano DF. An economic assessment of the social costs of highway salting and the efficiency of substituting a new deicing material. J Policy Anal Manage. 1992; 11(3): 397418.

http://dx.doi.org/10.2307/3325069

[50] Saka S, Kawamoto H, Miyafuji H, Yamauchi K, Masuda S, Nakamura $\mathrm{Y}$, et al. Method for producing alcohol by organic acid fermentation and direct hydrogenolysis. JP 2010239913 Patent 2010
[51] Saka S, Miyafuji H, Kohara Y, Kawamoto H. Method for producing acetic acid using anaerobic microorganism and method for producing bioethanol. US 8409832 Patent 2013.

[52] Ito $\mathrm{Y}$, Kawamoto $\mathrm{H}$, Saka $\mathrm{S}$. Efficient and selective hydrogenation of aqueous acetic acid on $\mathrm{Ru}-\mathrm{Sn} / \mathrm{TiO}_{2}$ for bioethanol production from lignocellulosics. Submitted to Fuel.

[53] Béligon V, Poughon L, Christophe G, Lebert A, Larroche C, Fontanille P. Improvement and modeling of culture parameters to enhance biomass and lipid production by the oleaginous yeast Cryptococcus curvatus grown on acetate. Bioresour Technol. 2015; 192: 582-91.

http://dx.doi.org/10.1016/j.biortech.2015.06.041

Received on 05-12-2015

Accepted on 17-12-2015

Published on 07-01-2016

(C) 2016 D.V. Nguyen et al.; Licensee Revotech Press.

This is an open access article licensed under the terms of the Creative Commons Attribution Non-Commercial License (http://creativecommons.org/licenses/by-nc/3.0/), which permits unrestricted, non-commercial use, distribution and reproduction in any medium, provided the work is properly cited. 